\title{
THE LEVEL OF DEVELOPMENT OF THE DIGITAL ECONOMY IN POLAND AND SELECTED EUROPEAN COUNTRIES: A COMPARATIVE ANALYSIS
}

\author{
Miroslaw MOROZ \\ Wroclaw University of Economics, Faculty of Economic Sciences, Wroclaw, Poland \\ e-mail: miroslaw.moroz@ue.wroc.pl
}

\begin{abstract}
An assessment of the degree of the development of the digital economy in Poland in comparison to chosen European countries is the main purpose of the paper. The methodology of the conducted research is based on the analysis of secondary sources and applying statistical methods. In order to make the comparison in methodically correct manner, synthetic measures of the development of the e-economy were used in the form of two indexes: NRI (Networked Readiness Index) and DESI (Digital Economy and Society Index). On the basis of available statistical data, four European countries were confronted with Poland. Results of the analysis indicate a relatively unfavorable situation of Poland.
\end{abstract}

Keywords: Digital economy, comparative analysis, Poland, Slovakia, Germany, Lithuania, Italy, NRI, DESI

\section{1}

Introduction

The digital economy, understood as using information and communication technologies (ICT) by the state, the business, and the society, is subject to ceaseless changes. A number of Internet users is increasing, a catalog of the available public online service is increasing, new business models are being made. In consequence, the digital economy constitutes the important component of the contemporary economic landscape.

In Poland, as in other countries, we are experiencing the development of e-economy. According to the analysis by consulting company, Deloitte, digital economy understood as the sum of the value added generated in connection with the use of the Internet has made $5.8 \%$ of GDP generated in 2012. Other indicators also show an upward trend (e.g., number of users, the value of e-commerce). Against this background, however, the question arises: what is the state of Polish digital economy? Whether in spite of generally positive tendencies isn't the rate of growth too small?

An assessment of the degree of the development of the digital economy in Poland in comparison to chosen European countries is the main purpose of the paper.

The methodology of the conducted research is based on the analysis of secondary sources and applying statistical methods. In order to make the comparison in methodically correct manner, synthetic measures of the development of the e-economy were used in the form of two indexes: NRI (Networked Readiness Index) and DESI (Digital Economy and Society Index). On the basis of available statistical data, four European countries were confronted with Poland. The comparative analysis is based on the data from the years 2002-2016.

\section{The specificity and pillars of the digital economy}

The phenomenon of the digital economy begins on a large scale at the end of the twentieth century. That's when the Internet is in economic uses. Flagship examples of enterprises operating in the virtual space started activity in the mid-nineties of the 20th century. Amazon, example of the online shop, was established in 1994. Auction service eBay was founded in 1995. In 1994, portal Yahoo.com - one of icons of the e-business - came into existence. In the same year, first text search engine Crawler.com was launched (Maciejewski, 2004, p.15). With regard to Poland, well-known Internet businesses were also opened in the 20th century. In 1999, a Merlin.pl online shop and an auction site Allegro.pl arose. In 1995, a portal WP.pl was launched. Starting online services of the government administration looked alike. FirstGov.gov, the first site of eadministration in the United States, was obligated 
to live in September 2000 (Osterweil, et al., 2007, p.151). In Poland, the project that realized egovernment ideas was "Gate of Poland", which started in 2005 .

In the technical sense, the Internet is a global network based on one protocol transmission information. With the worldwide adoption of the standard protocol TCP/IP (Transmission Control Protocol/Internet Protocol), it has become possible to de- velop digital economy regardless of economic sector or country. Another accelerator of e-economy was a web browser software - the way of communicating and presenting information based on a graphical user interface.

In this environment, you do not need to have a thorough knowledge of the syntax and rules of the programming language to be able to use the Internet (Combe, 2006, p.10).

Table 1. The growth rate of the number of web hosts worldwide in the years 1992-2015 (source: own calculation based on Internet System Consortium)

\begin{tabular}{|c|c|c|c|}
\hline Year & Host count & $\begin{array}{l}\text { Relative dynamics } \\
\text { (year-to-year) } \\
(\%)\end{array}$ & $\begin{array}{c}\text { Cumulative dynamics } \\
\text { (compared to 1992) } \\
\text { (\%) }\end{array}$ \\
\hline 1992 & 727000 & - & - \\
\hline 1993 & 1313000 & 180.61 & 180.61 \\
\hline 1994 & 2217000 & 168.85 & 304.95 \\
\hline 1995 & 4852000 & 218.85 & 667.40 \\
\hline 1996 & 9472000 & 195.22 & 1302.89 \\
\hline 1997 & 16146000 & 170.46 & 2220.91 \\
\hline 1998 & 29670000 & 183.76 & 4081.16 \\
\hline 1999 & 43230000 & 145.70 & 5946.35 \\
\hline 2000 & 72398092 & 167.47 & 9958.47 \\
\hline 2001 & 109574429 & 151.35 & 15072.14 \\
\hline 2002 & 147344723 & 134.47 & 20267.50 \\
\hline 2003 & 171638297 & 116.49 & 23609.12 \\
\hline 2004 & 233101481 & 135.81 & 32063.48 \\
\hline 2005 & 317646084 & 136.27 & 43692.72 \\
\hline 2006 & 394991609 & 124.35 & 54331.72 \\
\hline 2007 & 433193199 & 109.67 & 59586.41 \\
\hline 2008 & 541677360 & 125.04 & 74508.58 \\
\hline 2009 & 625226456 & 115.42 & 86000.89 \\
\hline 2010 & 732740444 & 117.20 & 100789.61 \\
\hline 2011 & 818374269 & 111.69 & 112568.68 \\
\hline 2012 & 888239420 & 108.54 & 122178.74 \\
\hline 2013 & 963518598 & 108.48 & 132533.51 \\
\hline 2014 & 1010251829 & 104.85 & 138961.74 \\
\hline 2015 & 1012706608 & 100.24 & 139299.40 \\
\hline
\end{tabular}


Interest in participating in the virtual space reflects the number of hosts and so the network devices (such as computer, network card, modem) participating in the exchange of data packets or providing network services. The increase in the number of hosts in the years 1992-2015 are presented in Table 1.

The data in Table 1 indicate that the active use of the Internet is growing at an exponential rate demand. In January 2015, more than one billion devices have assigned their own IP number. This clearly shows the necessity of being in the network and participate in the digital economy. The term digital economy is undoubtedly difficult for explicit defining. The difficulty stems from the intricacy and the complexity of the application of ICT. Generally speaking, you can identify four basic pillars that together create e-economy (Raisinghani, 2004, p.4):

- technical changes (the development of ICT),

- social changes caused by the popularization of the use of ICT,

- microeconomic level of changes,

- macroeconomic level of changes.

Each of these areas has a peculiar transformation leading to the new offer. The factors that make more widespread use of ICT are expansion of telecommunications connections (wired and wireless), increasing the speed of information flow, the implementtation of mobile technology, the emergence of the next version of web software (HTML), and software development in the direction of its greater efficiency and reliability.

Social changes concern the acceptance of the use of ICT in virtually all spheres of human activity (professional, personal, intimate, hobby, etc.). The Internet serves as a source of information, communication system, and a platform for purchasing and financial management. Modern people cannot imagine life without access to the Internet. This was even reflected in the official documents of the United Nations. The United Nations has DECLARED that "online freedom" is a human right in the resolution No. A / HRC / 32 / L.20 (Sandle).

At the microeconomic level, enterprises are a main beneficiary of ICT. The Internet is used by both traditional companies and Internet businesses, that is, companies operating in the virtual space. In the first group, the Internet is integrated into the traditional way of functioning. Generally, the use of ICT enhances the scope and speed of obtaining information, allowing companies to take appropriate decisions. Next with reference to the online businesses with the coming into existence of new business models, for example, an information intermediary is being bound (Oswald and Kleinemeier, p.131). These business models relate to three areas: e-services, emarketing, and e-commerce.

The fourth pillar of the digital economy refers to the level state or supranational structures. First of all, a question of provisions to facilitate the implementation of solutions based on ICT. In this regard, an electronic signature, a platform of the online competitive tendering, a computerization of national registers, and leading the e-government are examples. Implementing e-administration not only is significant legislative but also constitutes the encouraging factor, not to say in some situations forcing into using the e-economy.

The author acknowledges that the digital economy is an economy based on the wide use of ICT in terms of publication of the information, communication, and purchasing and production of hardware and software.

It should be pointed out that the digital economy now plays a big role, and its importance will grow with the entering in the production age generations not imagining a world without the Internet (generation Z). The digital economy brings a significant contribution to the economic development. According to the analysis of consulting firm Deloitte, a variety of activities undertaken within the framework of the digital economy have helped to generate a $5.8 \%$ of the Polish GDP in 2012 (Deloitte, 2013). In Great Britain, $5 \%$ of the population was used in sectors of the digital economy in 2015 (House of Commons Library). The Organization for Economic Co-operation and Development (OECD) indicates that productivity in business is growing by 5$10 \%$ year to year through the use of ICT (The Organization for Economic Co-operation and Development, 2016). 


\section{$3 \quad$ Measurement of Digital Economy}

The digital economy is thriving very much. Observation of individuals, companies, or government shows that both the extent and the intensity of the use of ICT are at a high level. However, in this context, a question is arising: how to make a proper assessment of the digital economy? What measures to take to properly and accurately reflect the development of the e-economy? What and how to measure?

Abovementioned questions can be organized in the specified scheme of conduct, consistent with metrology. The logical standard of the measurement should include the following elements (Barzilai-Nahon, 2006, p.269; Corrocher and Ordanini, 2002, p.1113):

- conceptualization of the notion of Digital Economy,

- operationalization of the abovementioned concept,

- collecting relevant data,

- evaluation and interpretation.

Undoubtedly, the digital economy is a concept not fully defined (with blurred boundaries), highly dynamic, the multifaceted being, and consequences far beyond the same e-economy. Therefore, the first step is to define the scope of meaning. Usually, it is assumed that the scope of the factors constituting the digital economy includes telecommunications' infrastructure and network; the use of ICT among individuals, companies, and government institutions; the impact of ICT on the society and economy (HaltiwangerandJarmin, 2002, p.13). These areas should be taken into account to measuring the digital economy methodically correct.

Drawing appropriate measuring variables up is a consecutive element of the measurement, in this context, with regard to the preparation of the relevant measures, reflecting the range of meanings, the dynamics of growth of users, the intensity of use, and the real potential of that data type. The indicated list, far incomplete, is an example of the determination of the extraction of specific measures. Depending on adopted criteria, a synthetic measure (index) is coming into existence of development of the digital economy.

For greater reliability of the index as a measurement tool, data sets of different nature (quantifiable and qualitative) collected on the basis of sectors constituting the digital economy, from multiple periods up to long time series, should be included in the index. An important aspect is also to define the importance (weights) of various indicators included in the index.

A data collection is the third component of the measurement. This data may come from existing databases or be collected as a consequence of a specially designed study (primary data). Using secondary data lets the wider range of comparing the e-economy with other indices. On the other hand, the inclusion of a personalized set of data from the personal research can raise the value of the index.

An evaluation and an interpretation of results are the last stage of the measurement. This stage is associated with the functions performed by a composite measure of the development of the digital economy. The most important functions of the e-economy measures are (Hanafizadeh et al., 2009, p.189):

- measurement of the degree of use of ICT,

- measuring the growth of the use of ICT and their impact on individuals, society, and the state,

- creating a framework and tools for the creation of economic policy, taking into account the possibilities of ICT in generating added value for people, businesses, and government.

The digital economy until now had many complex measures, which, to a greater or lesser degree, reflect the status and dynamics. Table 2 shows the most cited indexes of the digital economy.

The information contained in Table 2 lead to several conclusions. First, it is clear the desire to quantitative measurement of the digital economy. Kononova notes that at the end of 2015 , there are more than 20 indexes relating to economy (Kononova, 2015, p.938). 
Table 2. The most popular indexes of Digital Economy

(source: own elaboration based on Kononova, 2015, p.939)

\begin{tabular}{|l|l|l|c|c|c|}
\hline \multicolumn{1}{|c|}{ Index name } & \multicolumn{1}{|c|}{ Full name of index } & Originator & $\begin{array}{c}\text { First } \\
\text { publication }\end{array}$ & $\begin{array}{c}\text { Number } \\
\text { of covered } \\
\text { countries }\end{array}$ & $\begin{array}{c}\text { Number } \\
\text { of partial } \\
\text { indicators }\end{array}$ \\
\hline ISI & Information Society Index & IDC & 1997 & 53 & $<20$ \\
\hline ERI & E-Readiness Index & EIU & 2000 & 70 & $<100$ \\
\hline KEI & Knowledge Economy Index & WEF & 2005 & 140 & $<20$ \\
\hline EGDI & $\begin{array}{l}\text { E-Government Development } \\
\text { Index }\end{array}$ & UNPAP & 2002 & 182 & $<10$ \\
\hline IDI & ICT Development Index & ITU & 2002 & 154 & $<20$ \\
\hline DAI & Digital Access Index & ITU & 2003 & 178 & $<10$ \\
\hline TAI & Technology Achievement Index & UNDP & 2001 & 72 & $<10$ \\
\hline NRI & Networked Readiness Index & WEF & 2002 & 148 & $<80$ \\
\hline DOI & Digital Opportunity Index & ITU & 2005 & 181 & $<20$ \\
\hline ICT-OI & ICT Opportunity Index & ITU & 2005 & 183 & $<20$ \\
\hline ICT-DI & ICT Diffusion Index & UNCTAD & 2006 & 180 & $<10$ \\
\hline IS & Infostates & ORBICOM & 2003 & 183 & $<20$ \\
\hline DESI & $\begin{array}{l}\text { Digital Economy and Society } \\
\text { Index }\end{array}$ & EU & 2014 & 28 & $<40$ \\
\hline
\end{tabular}

This, on the one hand, shows the economic importance of the Internet usage and, on the other hand, points to the unfinished search for a universal set of gauges, measuring e-economy.

Second, there is a predominance of indicators that arose at the beginning of the 21 st century. Only two measures from the above list significantly deviate from that time span: ISI was created in the 20th century and DESI in 2014. This may reflect the period in which the expectations of the digital economy were the biggest.

Third, the domination of the originators of individual indexes emerged. The ITU (International Telecommunication Union) and various agencies of the United Nations (such as the UNPAP (United Nations Anti-poverty Alleviation Program), UNDP (United Nations Development Programme), and UNCTAD (United Nations Conference on Trade and Develop- ment) are in the first place. World Economic Forum (WEF) has created two indexes.

Fourth, virtually all indexes have covered more than 100 countries. This means that a relatively high ability to draw comparisons between the achievements in different countries in both the geographical and dynamic sense.

Fifth, there is considerable variation between the indexes because of the number of indicators used to measure. The range of variation ranges from 10 to 100 measures. Thus, some indicators are more reliable because they are based on more areas. In conclusion, the measurement of the development of the digital economy suffers rather from an excess of indexes than their scarcity. To make the selection mentioned indexes, one have to go to a more detailed level of analysis related to specific indicators within the index. 


\section{$4 \quad$ Methodology of design-selected indexes of the digital economy}

Owing to the limited size of this paper, as well as geographically circled area of interest (EU countries), two indexes will be selected for further analysis: NRI and DESI.

Rationale for selection of these complex measures include:

- coverage of research of the countries of the European Union,

- to take into account quantitative data indicators,

- comprehensiveness of research areas related to the use of ICT,

- the credibility of institutions developing and measuring the index.

The two abovementioned indexes of digital economy (NRI and DESI) meet the above criteria. On the other hand, they differ in two aspects. The first is the length of the time series. As mentioned in Table 2, the NRI index had 14 readings since 2002. In contrast, DESI took note of three editions. The second difference concerns the use of data from another source. In the case of the NRI, this is the statistical data of ITU, the World Bank, United Nations Educational, Scientific and Cultural Organization (UNESCO), and surveys carried out by the WEF. In turn, DESI is calculated on the basis of the statistical data collected by the European Commission's Directorate for communication networks, content, and technology and IHS company. Thus, taking into account both indexes makes the analysis more complementary.

NRI is a composite measure made up of four main categories (named also sub-indexes), 10 pillars (subcategories), and 53 indicators distributed across the particular pillars (Baller, et al., 2016, p.33). Table 3 shows a list of factors that make up the NRI.

Table 3. Methodological structure of Networked Readiness Index

(source: Baller, et al., 2016, p.35)

\begin{tabular}{|c|c|c|c|}
\hline Subindex & Pillar & $\begin{array}{l}\text { No. } \\
\text { of indicator }\end{array}$ & Indicators \\
\hline \multirow{18}{*}{$\begin{array}{l}\text { Environment } \\
\text { subindex }\end{array}$} & \multirow{9}{*}{$\begin{array}{l}\text { Political and } \\
\text { regulatory } \\
\text { environment } \\
\text { (first pillar) }\end{array}$} & 1.01 & Effectiveness of law-making bodies \\
\hline & & 1.02 & Laws relating to ICTs \\
\hline & & 1.03 & Judicial independence \\
\hline & & 1.04 & Efficiency of legal system in settling disputes \\
\hline & & 1.05 & Efficiency of legal system in challenging regulations \\
\hline & & 1.06 & Intellectual property protection \\
\hline & & 1.07 & Software piracy rate, percentage of software installed \\
\hline & & 1.08 & Number of procedures to enforce a contract \\
\hline & & 1.09 & Number of days to enforce a contract \\
\hline & \multirow{9}{*}{$\begin{array}{l}\text { Business and } \\
\text { innovation } \\
\text { environment } \\
\text { (second pillar) }\end{array}$} & 2.01 & Availability of latest technologies \\
\hline & & 2.02 & Venture capital availability \\
\hline & & 2.03 & Total tax rate, percentage of profits \\
\hline & & 2.04 & Number of days to start a business \\
\hline & & 2.05 & Number of procedures to start a business \\
\hline & & 2.06 & Intensity of local competition \\
\hline & & 2.07 & Tertiary education gross enrollment rate, $\%$ \\
\hline & & 2.08 & Quality of management schools \\
\hline & & 2.09 & $\begin{array}{l}\text { Government procurement of advanced technology } \\
\text { products }\end{array}$ \\
\hline
\end{tabular}


Table 3. Methodological structure of Networked Readiness Index, cont. (source: Baller, et al., 2016, p.35)

\begin{tabular}{|c|c|c|c|}
\hline Subindex & Pillar & $\begin{array}{l}\text { No. } \\
\text { of indicator }\end{array}$ & Indicators \\
\hline \multirow{11}{*}{$\begin{array}{l}\text { Readiness } \\
\text { Subindex }\end{array}$} & \multirow{4}{*}{$\begin{array}{l}\text { Infrastructure } \\
\text { (third pillar) }\end{array}$} & 3.01 & Electricity production, $\mathrm{kWh} /$ capita \\
\hline & & 3.02 & Mobile network coverage, $\%$ population \\
\hline & & 3.03 & International Internet bandwidth, $\mathrm{kb} / \mathrm{s}$ per user \\
\hline & & 3.04 & Secure Internet servers per million population \\
\hline & \multirow{3}{*}{$\begin{array}{l}\text { Affordability } \\
\text { (fourth pillar) }\end{array}$} & 4.01 & Prepaid mobile cellular tariffs, PPP \$/min. \\
\hline & & 4.02 & Fixed broadband Internet tariffs, PPP \$/month \\
\hline & & 4.03 & $\begin{array}{l}\text { Internet and telephony sectors competition index, } 0-2 \\
\text { (best) }\end{array}$ \\
\hline & \multirow{4}{*}{$\begin{array}{l}\text { Skills } \\
\text { (fifth pillar) }\end{array}$} & 5.01 & Quality of education system \\
\hline & & 5.02 & Quality of math and science education \\
\hline & & 5.03 & Secondary education gross enrollment rate, $\%$ \\
\hline & & 5.04 & Adult literacy rate, $\%$ \\
\hline \multirow{16}{*}{ Usage subindex } & \multirow{7}{*}{$\begin{array}{l}\text { Individual } \\
\text { usage } \\
\text { (sixth pillar) }\end{array}$} & 6.01 & Mobile phone subscriptions per 100 population \\
\hline & & 6.02 & Percentage of individuals using the Internet \\
\hline & & 6.03 & Percentage of households with computer \\
\hline & & 6.04 & Households with Internet access, $\%$ \\
\hline & & 6.05 & $\begin{array}{l}\text { Fixed broadband Internet subscriptions per } 100 \text { popula- } \\
\text { tion }\end{array}$ \\
\hline & & 6.06 & $\begin{array}{l}\text { Mobile broadband Internet subscriptions per } 100 \text { popu- } \\
\text { lation }\end{array}$ \\
\hline & & 6.07 & Use of virtual social networks \\
\hline & \multirow{6}{*}{$\begin{array}{l}\text { Business usage } \\
\text { (seventh pillar) }\end{array}$} & 7.01 & Firm-level technology absorption \\
\hline & & 7.02 & Capacity for innovation \\
\hline & & 7.03 & PCT patent applications per million population \\
\hline & & 7.04 & ICT use for business-to-business transactions \\
\hline & & 7.05 & Business-to-consumer Internet use \\
\hline & & 7.06 & Extent of staff training \\
\hline & \multirow{3}{*}{$\begin{array}{c}\text { Government } \\
\text { usage } \\
\text { (seventh pillar) }\end{array}$} & 8.01 & Importance of ICTs to government vision \\
\hline & & 8.02 & Government Online Service Index, 0-1 (best) \\
\hline & & 8.03 & Government success in ICT promotion \\
\hline
\end{tabular}


Table 3. Methodological structure of Networked Readiness Index, cont. (source: Baller, et al., 2016, p.35)

\begin{tabular}{|c|c|c|c|}
\hline Subindex & Pillar & $\begin{array}{c}\text { No. } \\
\text { of indicator }\end{array}$ & Indicators \\
\hline \multirow{8}{*}{ Impact subindex } & \multirow{4}{*}{$\begin{array}{c}\text { Economic im- } \\
\text { pacts } \\
\text { (ninth pillar) }\end{array}$} & 9.01 & Impact of ICTs on business models \\
\hline & & 9.02 & ICT PCT patent applications per million population \\
\hline & & 9.03 & Impact of ICTs on organizational models \\
\hline & & 9.04 & Knowledge intensive jobs, percentage of workforce \\
\hline & \multirow{4}{*}{$\begin{array}{c}\text { Social impacts } \\
\text { (tenth pillar) }\end{array}$} & 10.01 & Impact of ICTs on access to basic services \\
\hline & & 10.02 & Internet access in schools \\
\hline & & 10.03 & ICT use and government efficiency \\
\hline & & 10.04 & E-Participation Index, 0-1 (best) \\
\hline
\end{tabular}

In total, the NRI index consists of 53 indicators from areas such as the environment, ready to use, intensity of use, and impact. In fact, the NRI is a complex measure, covering its scope of many factors, from the efficiency of parliament until the impact of the use of ICT. It is worth noting that each subcategory has the same importance (weight) in the subindex.

Nearly half of the $53 \mathrm{~m}$ is based on "hard" statistical data collected annually by the ITU, the World Bank, and the UNESCO. Qualitative data are collected in the annual survey carried out by the WEF.

The second index considered in this study is the DESI. Juxtaposing belonging and affiliated states with the European Union, effected under the angle of the e-business, the e-society, and e-administration constitutes DESI. Table 4 provides a list of indicators that make up the index of DESI.

Table 4. Methodological structure of Digital Economy and Society Index (source: European Commission, 2016, p.5)

\begin{tabular}{|c|c|c|c|}
\hline $\begin{array}{c}\text { Principal } \\
\text { dimensions }\end{array}$ & Subdimensions & $\begin{array}{c}\text { No. } \\
\text { of indicator }\end{array}$ & Indicators \\
\hline \multirow{7}{*}{ Connectivity } & \multirow{2}{*}{ Fixed Broadband } & $1 \mathrm{a} 1$ & Fixed Broadband (BB) Coverage \\
\hline & & $1 \mathrm{a} 2$ & Fixed BB Take-up \\
\hline & \multirow{2}{*}{$\begin{array}{l}\text { Mobile Broad- } \\
\text { band }\end{array}$} & $1 \mathrm{~b} 1$ & Mobile BB Take-up \\
\hline & & $1 \mathrm{~b} 2$ & Spectrum \\
\hline & \multirow{2}{*}{ Speed } & $1 \mathrm{c} 1$ & NGA Coverage \\
\hline & & $1 \mathrm{c} 2$ & Subscriptions to Fast BB \\
\hline & Affordability & $1 \mathrm{~d} 1$ & Affordability 1d1 Fixed BB Price \\
\hline \multirow{4}{*}{ Human Capital } & \multirow{2}{*}{$\begin{array}{c}\text { Basic Skills and } \\
\text { Usage }\end{array}$} & $2 \mathrm{a} 1$ & Internet Users \\
\hline & & $2 \mathrm{a} 2$ & Basic Digital Skills \\
\hline & \multirow{2}{*}{$\begin{array}{l}\text { Advanced skills } \\
\text { and Development }\end{array}$} & $2 \mathrm{~b} 1$ & ICT Specialists \\
\hline & & $2 \mathrm{~b} 2$ & STEM Graduates \\
\hline
\end{tabular}


Table 4. Methodological structure of Digital Economy and Society Index, cont. (source: European Commission, 2016, p.5)

\begin{tabular}{|c|c|c|c|}
\hline $\begin{array}{l}\text { Principal } \\
\text { dimensions }\end{array}$ & Subdimensions & $\begin{array}{c}\text { No. } \\
\text { of indicator }\end{array}$ & Indicators \\
\hline \multirow{7}{*}{ Use of Internet } & \multirow{3}{*}{ Content } & $3 \mathrm{a} 1$ & News \\
\hline & & $3 \mathrm{a} 2$ & Music, Videos and Games \\
\hline & & $3 \mathrm{a} 3$ & Video on Demand \\
\hline & \multirow{2}{*}{ Communication } & $3 \mathrm{~b} 1$ & Video Calls \\
\hline & & $3 \mathrm{~b} 2$ & Social Networks \\
\hline & \multirow{2}{*}{ Transactions } & $3 \mathrm{c} 1$ & Banking \\
\hline & & $3 \mathrm{c} 2$ & Shopping \\
\hline \multirow{8}{*}{$\begin{array}{c}\text { Integration of Digital } \\
\text { Technology }\end{array}$} & \multirow{5}{*}{$\begin{array}{l}\text { Business } \\
\text { digitization }\end{array}$} & $4 \mathrm{a} 1$ & Electronic Information Sharing \\
\hline & & $4 \mathrm{a} 2$ & RFID \\
\hline & & $4 \mathrm{a} 3$ & Social Media \\
\hline & & $4 \mathrm{a} 4$ & e-Invoices \\
\hline & & $4 \mathrm{a} 5$ & Cloud \\
\hline & \multirow{3}{*}{ E-commerce } & $4 \mathrm{~b} 1$ & SMEs Selling Online \\
\hline & & $4 \mathrm{~b} 2$ & E-commerce Turnover \\
\hline & & $4 \mathrm{~b} 3$ & Selling Online Cross-border \\
\hline \multirow{4}{*}{$\begin{array}{l}\text { Digital Public } \\
\text { Services }\end{array}$} & \multirow{4}{*}{ E-government } & $5 \mathrm{a} 1$ & E-government Users \\
\hline & & $5 \mathrm{a} 2$ & Pre-filled Forms \\
\hline & & $5 \mathrm{a} 3$ & Online Service Completion \\
\hline & & $5 \mathrm{a} 4$ & Open Data \\
\hline
\end{tabular}

The substantive scope of DESI is similar to the previous NRI, although the number of measures is smaller. Essentially, DESI is based on the 30 measures that reflect Internet usage, e-public services, development of infrastructure, and quality human capital.

Components of the index do not have equal weights. Connectivity and digital skills each contribute $25 \%$ to the total score. The integration of digital technology accounts for $20 \%$, whereas the use of the Internet as well as digital public services contribute equally $(15 \%)$.

Taking these aspects into account, it should be noted that both the NRI and DESI can, to a large extent, validly reflect the degree of Member States in the field of the digital economy. Consequently, both indexes are suitable for the construction of the ranking of countries in terms of the development of the e-economy.

\section{The research methodology}

The main objective of the article is to assess the degree of development of the digital economy in Poland compared to selected European countries. This objective arises from the adopted, comparative perspective. The modern world is heavily globalized. Similarly, the Internet knows no physical or administrative boundaries. Therefore, there is a research problem relating to the extent, scope, and pace 
of implementation of digital solutions in the various Member States.

Research methodology is based on the analysis of secondary sources and the use of statistical methods. The choice of research methods arises from the adopted research problem and research aim.

In order to make the comparison in methodically correct manner, synthetic measures of the development of the e-economy were used in the form of two indexes: NRI and DESI. The rationale for the selection of these indexes is their multifaceted and extended range of analysis up to many aspects of digitization and a large part of strictly quantitative indicators.

On the basis of available statistical data, four countries were selected, which then were confronted with Poland in terms of the development of the digital economy. Comparative analysis of four Member States only were due to the fact that the number of States of the European Union (along with the as- sociated countries) is 28. Analysis of 28 States would exceed the volume of this paper. Therefore, the author has decided to incorporate into the comparison one European country that meets three requirements:

- geographical proximity in relation to Poland,

- belonging to one of the cluster of countries arranged based on the development and the growth rate of the e-economy (see Table 5),

- ban on repeating country in analysis from the group that already has its representative in the comparative analysis.

Further discussion requires the second and third conditions, that is, the assignment of the European States to a given classification group (cluster). On the basis of own study, the European Commission divided EU member states according to two factors: the average rate of development and the current stage of development of the digital economy. Details in this regard are presented in Table 5 .

Table 5. Classification of EU countries according to progress and performance towards Digital Economy (source: Mateus, 2016, p.13)

\begin{tabular}{|c|l|l|l|}
\hline \multicolumn{2}{|c|}{} & \multicolumn{2}{c|}{ The rate of growth relative to the average for the European Union } \\
\cline { 3 - 4 } \multicolumn{2}{|c|}{} & \multicolumn{1}{|c|}{$<2 \%$} & \multicolumn{1}{c|}{$>2 \%$} \\
\hline \multirow{2}{*}{$\begin{array}{c}\text { The level of devel- } \\
\text { opment relative } \\
\text { to the EU average }\end{array}$} & points & $\begin{array}{l}\text { "Lagging ahead": } \\
\text { Sweden, Estonia, Denmark, Fin- } \\
\text { land, Belgium, United Kingdom, } \\
\text { Ireland, Luxembourg, Lithuania }\end{array}$ & $\begin{array}{l}\text { Netherland, Estonia, Germany, Aus- } \\
\text { tria, Portugal }\end{array}$ \\
\cline { 2 - 4 } & $\begin{array}{c}<0.52 \\
\text { points }\end{array}$ & $\begin{array}{l}\text { "Falling behind": } \\
\text { France, Czech Republic, Slovakia, } \\
\text { Hungary, Poland, Cyprus, Bulgaria }\end{array}$ & Spain, Latvia, Italy, Croatia, Romany \\
\hline
\end{tabular}

On the basis of the adopted criteria and above classification for the comparison, the following states were chosen: Lithuania, Germany, Slovakia, and Italy. The first three of them border with Poland and represent three of the four clusters. However, the emergence of the problem was with a group of "catching up." Latvia is omitted in the analysis, because of the resemblance to Lithuania, the state, which has already been selected for analysis. It was considered that the second closest in the geographical sense country is Italy.

Data on the basis of which the analyses are performed are derived from the years 2002-2016. 
6

\section{Comparative analysis of Poland and selected European countries with regard to digital economy}

The primary goal of this paper is a comparative analysis of the Poland and other States with regards to digital economy. NRI can be thought of as the ranking of the development of the digital economy. Furthermore, NRI is developed from year 2002, so it gives traceability of changes in terms of time. Table 6 shows the place of Poland in the NRI from 2002 to 2016 .

Table 6. The nominal place of Poland according to the NRI

(source: Baller, 2016, p.159; Dutta, et al., 2003, pp.11,13,16; World Economic Forum, 2009, pp.11,12,13; Bilbao-Osorio, 2014, p.208)

\begin{tabular}{|l|c|c|c|c|c|}
\hline \multicolumn{1}{|c|}{ Level of measurement } & 2002 & 2008 & 2012 & 2014 & 2016 \\
\hline General classification (NRI level) & 38 & 68 & 49 & 54 & 42 \\
\hline Subindex environment & 47 & 47 & 58 & 55 & 48 \\
\hline Subindexreadiness & 45 & 62 & 38 & 39 & 28 \\
\hline Subindex usage & 34 & 80 & 49 & 54 & 49 \\
\hline Subindex impact & NA & NA & 66 & 78 & 59 \\
\hline The number of covered countries & 82 & 134 & 142 & 148 & 139 \\
\hline
\end{tabular}

Development of the digital economy in Poland, measured at the level of the main index of the NRI, is subject to fluctuations in 2002-2016. Years inheritance are interspersed with periods of growth. However, the general trend is positive, because the place of Polish gradually increased. Similar trends occur also in relation to the particular subindexes. In this respect, the best is the situation in the category the readiness and environment. Definitely less rated is the subindex impact.

When analyzing the situation of Poland, one should consider that in many years of preparing NRI has evolved the number of countries subject to study. The relative place of Poland by taking into account the number of states that are included in index in a given year is presented in Table 7 .

Table 7. The relative place of Poland (weighted number of countries) according to the NRI (source: own calculation)

\begin{tabular}{|l|c|c|c|c|c|}
\hline \multicolumn{1}{|c|}{ Level of measurement } & 2002 & 2008 & 2012 & 2014 & 2016 \\
\hline $\begin{array}{l}\text { General classification } \\
\text { (NRI level) }\end{array}$ & $46.34 \%$ & $50.75 \%$ & $34.51 \%$ & $36.49 \%$ & $30.22 \%$ \\
\hline Subindex environment & $57.32 \%$ & $35.07 \%$ & $40.85 \%$ & $37.16 \%$ & $34.53 \%$ \\
\hline Subindexreadiness & $54.88 \%$ & $46.27 \%$ & $26.76 \%$ & $26.35 \%$ & $20.14 \%$ \\
\hline Subindex usage & $41.46 \%$ & $59.70 \%$ & $34.51 \%$ & $36.49 \%$ & $35.25 \%$ \\
\hline Subindex impact & NA & NA & $46.48 \%$ & $52.70 \%$ & $42.45 \%$ \\
\hline
\end{tabular}

Having regard to the relative place of Poland (weighted number of countries), it is clear that the place of Polish is rising steadily. Referring to the main index NRI, Polish position has increased by 16 percentage points. Even greater progress in terms of readiness and environment was noticed. 
In turn for subindexes of the impact and usage, only a single-digit growth is seen.

This general positive picture is not reflected in the data contained in the second index DESI.
Table 8 provides information relating to the place of Poland among countries belonging to the European Union or its affiliates.

Table 8. The nominal place of Poland according to the index DESI

(source: European Commission, 2015, 2016)

\begin{tabular}{|l|c|c|c|}
\hline \multicolumn{1}{|c|}{ Level of measurement } & 2014 & 2015 & 2016 \\
\hline $\begin{array}{l}\text { General classification } \\
\text { (DESI level) }\end{array}$ & 24 & 22 & 22 \\
\hline Connectivity & 21 & 24 & 24 \\
\hline Human Capital & 22 & 20 & 22 \\
\hline Use of Internet & 24 & 23 & 22 \\
\hline Integration of Digital Technology & 25 & 26 & 15 \\
\hline Digital Public Services & 15 & 12 & 28 \\
\hline Number of covered countries & 28 & 28 & 28 \\
\hline
\end{tabular}

Analyzing above mentioned data of DESI index can be seen Polish weak position compared with other European countries (on an average of 22 place to 28 countries).

The only "lighter" category is e-government, which took fifteenth place. However, even in this case, you can see large fluctuations in the indicator from year to year. While for the remaining principal dimensions, you can see the weakness of analyzed country compared to other countries of our continent.

Presented data is inducing to the conclusion that as far as against countries around the world, the position of Poland does not look bad, but comparison to European countries changes the positive picture. Therefore, the author decided to analyze Poland, Lithuania, Slovakia, Germany, and Italy at a lower level of aggregation. These countries were included in the research framework. Analysis was performed based on year 2016 .

First, they analyzed the data collected for the purposes of the NRI. The results of analysis are shown in Figure 1 and Table 9. The 10 categories included in the analysis can be divided into 3 groups: above average for the analyzed population, at the level of average, and below average. In the Infrastructure and the Affordability subcategories, Poland occupies the second place, after Germany. In turn, environmental factors and the skills of Poland takes the middle value. With reference to these three factors, Germany and Lithuania are overtaking us, whereas in taking back to the ability also Italy. Whereas for the remaining five subcategories related to the intensity of use of the Internet, as well as the impact of ICT on economic and social issues, Poland occupies the last place. Picture emerging from the comparison is particularly alarming, because the largest value added is just hiding in categories of the impact, the usage, and the skills. In turn, the category Affordability means that despite the passing years, Poland is still based on cost advantages.

Generalizing Poland occupies the central position in the analyzed five countries, although closer to its weakest countries (with an average of 50 vs. 54 and 57) than to the leader (Germany with an average of 16). 
Table 9. Comparative analysis of subcategory - according to the NRI (source: own elaboration based on Baller, et al., 2016, pp.99, 115, 129, 159, 170)

\begin{tabular}{|l|c|c|c|c|c|}
\hline & Poland & Lithuania & Germany & Slovakia & Italy \\
\hline Political and regulatory environment & 57 & 41 & 16 & 74 & 96 \\
\hline Business and innovation environment & 53 & 31 & 28 & 60 & 68 \\
\hline Infrastructure & 35 & 57 & 12 & 70 & 39 \\
\hline Affordability & 11 & 34 & 5 & 51 & 52 \\
\hline Skills & 40 & 26 & 8 & 72 & 37 \\
\hline Individual usage & 42 & 35 & 18 & 34 & 37 \\
\hline Business usage & 64 & 29 & 6 & 48 & 52 \\
\hline Government usage & 82 & 33 & 30 & 73 & 62 \\
\hline Economic impacts & 44 & 27 & 10 & 41 & 39 \\
\hline Social impacts & 74 & 25 & 30 & 47 & 62 \\
\hline Mean & 50.2 & 33.8 & 16.3 & 57 & 54.4 \\
\hline
\end{tabular}

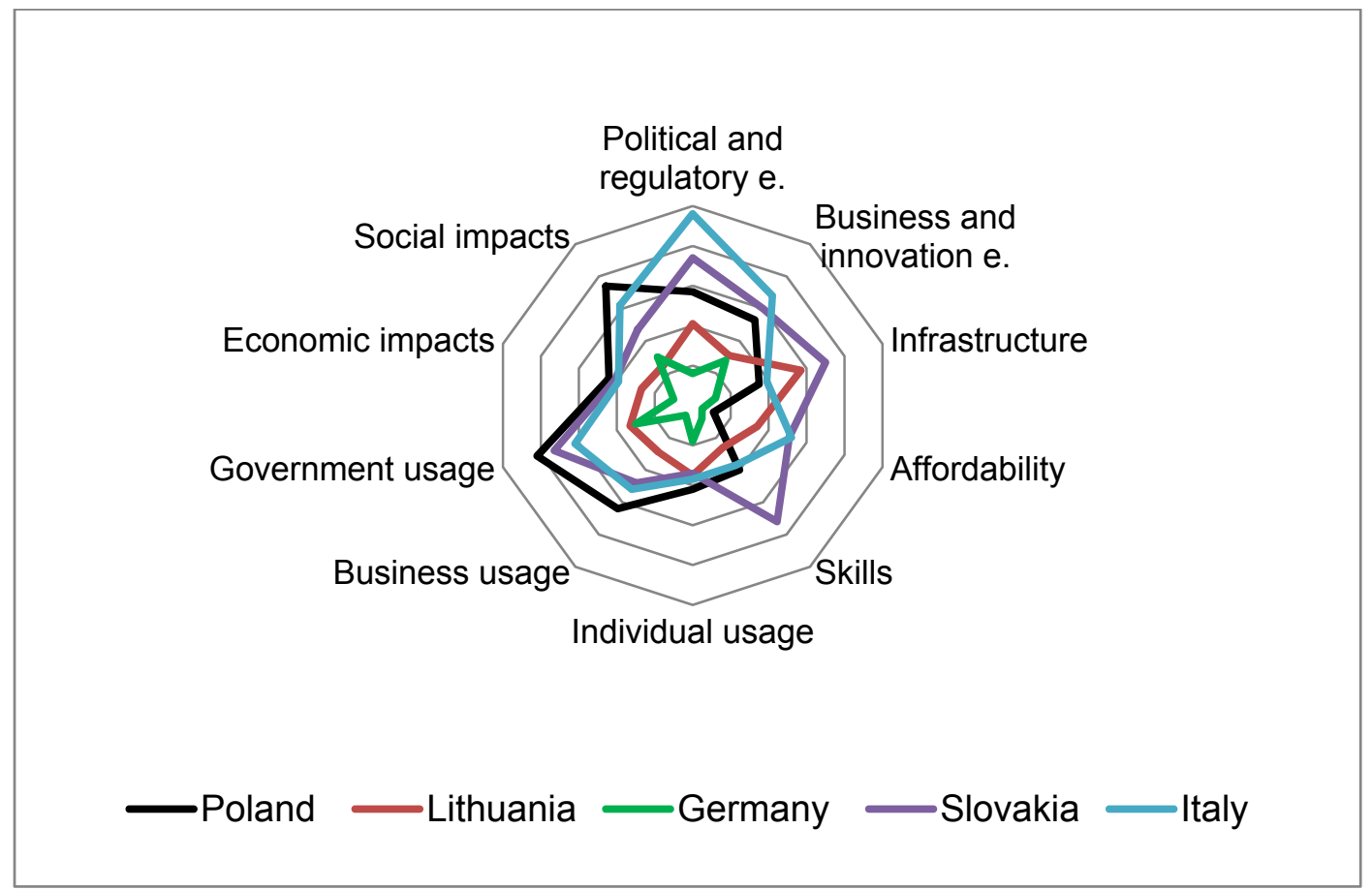

Figure 1. Comparative analysis of subcategory - according to the NRI (graphical interpretation, where: e. - environment)

The next set of analyzed data delivered the DESI. Fig. 2 and Table 10 are showing the place of Poland in the diameter of the DESI. Poland takes the penultimate fourth place in relation to the three categories (Connectivity, Human Capital, the Use of the Internet).
Invariably, Italy is in the last place. In turn, the Integration of Digital Technology is a weak point of Poland (the last place). In this regard, we are in a clear backwardness compared to the analyzed group of countries. 
Table 10. Comparative analysis of subcategory - according to the DESI

(source: own elaboration based on: European Commission, 2016)

\begin{tabular}{|l|c|c|c|c|c|}
\hline & Poland & Lithuania & Germany & Slovakia & Italy \\
\hline Connectivity & 24 & 7 & 8 & 21 & 27 \\
\hline Human Capital & 22 & 19 & 9 & 16 & 24 \\
\hline Use of Internet & 22 & 10 & 13 & 18 & 28 \\
\hline Integration of Digital Technology & 25 & 8 & 7 & 19 & 20 \\
\hline Digital Public Services & 15 & 12 & 18 & 26 & 17 \\
\hline Mean & 21.6 & 11.2 & 11 & 20 & 23.2 \\
\hline
\end{tabular}

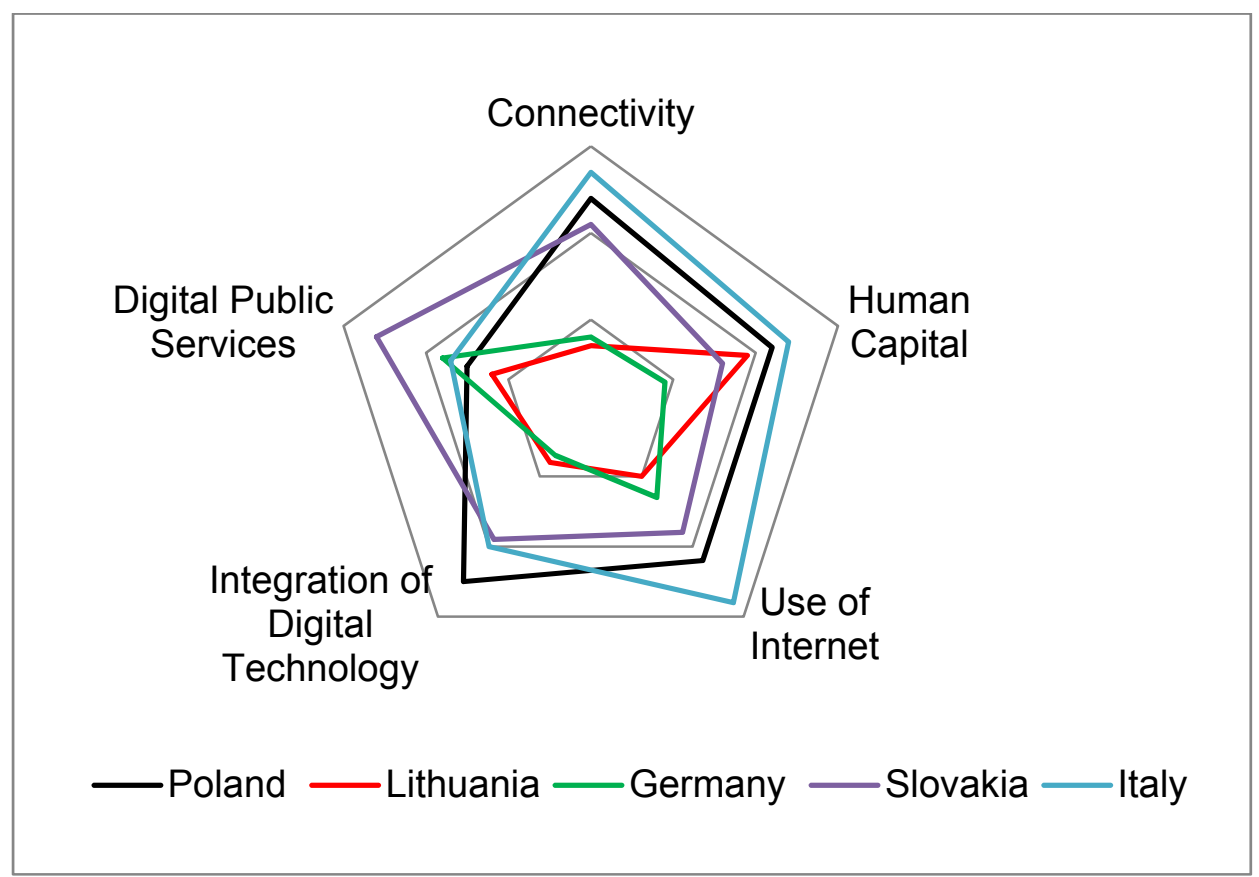

Figure 2. Comparative analysis of subcategory - according to the DESI (graphical interpretation)

The only comforting aspect is the high, second place, in the field of Digital Public Services. To tell the truth, so high position is not consistent with the data collected for the NRI. This is, however, a slightly different set of meters. Generalizing, the position of Poland is similarly weak in the cross section of virtually all analyzed categories, reflecting the arithmetic average of each category.

\section{Conclusion}

The comparative analysis is pointing out to the disadvantage of Poland in terms of the development of the digital economy in comparing to analyzed EU countries. Analysis of both the NRI and DESI causes the same conclusion. Only in case of e-administration, the DESI has a gentler pronunciation.

Admittedly, looking at the nominal position of Poland in frames of the NRI, it is possible to be under the impression that the state is relatively good. However, more thorough analysis, taking into account the number of states being subject to analysis, as well as analysis of the DESI are pointing at the worrying level of the development of the Polish digital economy.

Development gap is particularly strongly visible in relation to the degree of use of ICT systems integration and the impact of ICT on the economy and 
society. Preliminary nature of this study, as well as modest volume, does not enable a closer look at the causes of such a state. However, the author's own observations and the analysis of available secondary data invest reasons for the relative backwardness of the Polish in the following factors: a weak state influence on the popularization of computerization (e.g., eID, electronic signature system, the system records of vehicles), also on the side of business (e.g., selective areas of interest), or on people (gaps in abilities of the service of the software). Of course, a wider analysis of the causes (and effects) requires a separate study.

The synthetic indexes used for the analysis, NRI and DESI, are based on the system (linked), comprehensive (many areas), multicriterial (many meters) approach to measure the degree of development of the digital economy. Both indexes include meters affecting, directly or indirectly, the level of the digital economy. In the case of indirect factors, there is a strong causal relationship, the basis for this type of index. It is also worth to emphasize that the NRI undergo periodical modifications and is changed with the development of the digital economy. It should be assumed that the DESI will be also be subjected to alterations in the future.

The relatively weak position of the Polish digital economy is forcing to take streamlining action. Many projects (both public and private) that affect the level of development of the digital economy is underway in Poland. In this context, it is worth quoting activities taken by the EU funds. It concerns both the national level and regional level programs. The list of measures aimed at the acceleration of the digital economy includes, among others:

- Operational Programme Digital Poland:

- Measure 1.1 Elimination of territorial differences in the ability to access broadband Internet with high bandwidth,

- Measure 2.1 High availability and quality of public e-services,

- Regional Operational Programmes (among others):

- Silesian region, measure 3.3 ICT in business,

- Lower Silesian Voivodeship, measure 2.1 E-public services,
- Lodz Province, measure VII.1 Information and communication technology,

- Mazowieckie Province, Measure 2.3 Information and Communication Technologies for Small and Medium-Sized Enterprises.

Polish development strategies that are currently being developed emphasize the importance of digitization for the future state of the economy.

For example, the "strategy for responsible development" in each of the objectives refers to the use of ICT. However, the question arises whether financial resources are sufficient and goals are properly set from the point of view of the nature of the digital economy. Warning are the results of the implementation of a project aimed at the development of e-services in Poland (one of former measure of Operational Programme Innovative Economy) (Moroz, 2014).

Place in the ranking of Polish development in term of the digital economy is made up of two factors the efforts within the country and the measures taken in other countries. The world does not stand still, despite the efforts in the position of Poland on the international stage are made up of external and internal activities. The realization of this fact should lead to even greater efforts for the development of the digital economy.

\section{References}

[1] Baller, S., Dutta, S., Lanvin, B., 2016. The Global Information Technology Report 2016. Innovating in the Digital Economy. World Economic Forum and INSEAD, Geneva.

[2] Barzilai-Nahon, K., 2006. Gaps and bits: Conceptualizing measurements for digital divide/s. The information society, Vol. 22, No. 5, pp.269278.

[3] Bilbao-Osorio, B., Dutta, S., Lanvin, B., 2014. The Global Information Technology Report 2014. Rewards and Risks of Big Data. World Economic Forum and INSEAD, Geneva.

[4] Combe C., 2006. Introduction to E-business. Management and Strategy. Oxford: Butterworth - Heinemann.

[5] Corrocher, N., Ordanini, A., 2002. Measuring the digital divide: A framework for the analysis 
of cross-country differences. Journal of Information Technology, Vol. 17, No.1, 2002, pp.919.

[6] Deloitte: e-nnovation, 2013, http://www.deloitte. com/view/pl_pl/pl/9e6fd0e8b79e1410VgnVCM 3000003456f70aRCRD.htm (accessed on 14 December 2016).

[7] Dutta, S., Lanvin, B.,Paua F., 2003. The Global Information Technology Report 2002-2003: Readiness for the networked World. Oxford: Oxford University Press.

[8] European Commission (a): DESI 2016 Country Profiles, https://ec.europa.eu/digital-single market/en/news/desi-2016-country-profiles (acessed on 2016.12.14).

[9] European Commission (b): The Digital Economy and Society Index (DESI) 2015 - Country Profiles, http://nhit.hu/dokumentum/69/DESIcount ryprofileALL_r.pdf (accessed on 2016.12.14).

[10] European Commission, Directorate-General for Communications Networks, Content and Technology: DESI 2016 Digital Economy and Society Index. Methodological note, http://ec.europa.eu/ newsroom/dae/document.cfm?doc_id=8846 (accessed on 2016.12.14).

[11] Haltiwanger, J., Jarmin, R.S., 2002. Measuring the digital economy. In: Understanding the Digital Economy: Data, Tools and Research (ed. Brynjolfsson, E., Kahin B.), Cambridge 2002, pp.13-33.

[12] Hanafizadeh, P., Hanafizadeh, M.R., Khodabakhshi, M., 2009. Taxonomy of e-readiness assessment measures. In: International Journal of Information Management, Vol. 29, No. 3, 2009, pp.189-195.

[13] House of Commons Library: Digital economy: statistics and policy, http://researchbriefings. parliament.uk/ResearchBriefing/Summary/CBP7610\#fullreport (accessed on 2016.12.14).

[14] Internet System Consortium (ISC): Internet Domain Survey, https://www.isc.org/network/ survey/ (accessed on 2016.12.14).

[15] Kononova, K., 2015. Some Aspects of ICT Measurement: Comparative Analysis of EIndexes [at] The $7^{\text {th }}$ International Conference on Information and Communication Technology, Kavala 2015, pp. 938-945.
[16] Maciejewski, T., 2004. Firma w Internecie (Company on the Internet). Kraków: Oficyna Ekonomiczna.

[17] Mateus A., 2016. DESI/I-DESI Digital Economy and Society Index. European Commission, Brussels.

[18] Moroz M., 2014. Ocena funkcjonowania działania 8.1 „Wspieranie działalności gospodarczej w dziedzinie gospodarki elektronicznej” Programu Operacyjnego Innowacyjna Gospodarka (Evaluation of the functioning of Measure 8.1 "Supporting economic activity in the field of electronic economy" of the Operational Program Innovative Economy). Studia i materiaty Polskiego Stowarzyszenia Zarzadzania Wiedza (Studies and materials of the Polish Knowledge Management Association), No. 71, 2014, pp.116-127.

[19] Osterweil, L.J., Millett, L.I., Winston, J.D., 2007. Social Security Administration Electronic Service Provision: A Strategic Assessment. The National Academies Press. Washington, DC,doi: 10.17226/11920.

[20] Oswald, G., Kleinemeier, M., 2016. Shaping the Digital Enterprise: Trends and Use Cases in Digital Innovation and Transformation, Springer.

[21] The Organization for Economic Co-operation and Development (OECD): OECD Observer i-Sheet: The digital economy. http://oecdobser ver.org/news/categoryfront.php/id/2270/Digital economy_2016.html (accessed on 2016.12.14).

[22] Raisinghani, M.S., 2004. Business Intelligence in the Digital Economy: Opportunities, Limitations, and Risks. Idea Group Publishing, Hershey.

[23] Sandle, T. UN thinks internet access is a human right, http://www.businessinsider.com/un-saysinternet-access-is-a-human-right-2016-7? IR=T (accessed on 2016.12.14).

[24] World Economic Forum(a) - Gauging the Networked Readiness of Nations: Findings from the Networked Readiness, http://www.insead.edu/ facultyresearch/centres/elab/rightnav/documents 1.1_GaugingtheNetworkedReadinessofNations _ 000.pdf (accessed on 2016.12.14). 